\title{
PENERAPAN MODEL COOPERATIF SCRIPT SEBAGAI UPAYA MENINGKATKAN HASIL BELAJAR MATEMATIKA SISWA SD 4 KARANGMALANG
}

\section{Siti Rosiah ${ }^{凶}$}

SD 4 Karangmalang, Gebog, Kudus

\begin{abstract}
Info Artikel Abstract
Sejarah Artikel:

Diterima 2 Okt 2019

Direvisi 31 Okt 2019

Disetujui 6 Nov 2019

Keywords:

Cooperatif Script,

Arithmetic Operations.

\section{Paper type:}

Research paper

The problem at SD 4 Karangmalang is the low activity and mathematics learning outcomes of mixed count operations material. This study aims to: (1) improve mathematics learning activities about mixed count operations with cooperative script learning models, and (2) improve mathematical learning outcomes about mixed count operations with cooperative script learning models. Classroom action research was conducted on students of class VI Karangmalang 4 elementary school in the first semester of 2017/2018 with 13 students consisting of 9 male students and 4 female students. The method used in this research is classroom action research consisting of 2 cycles, each cycle consisting of 4 stages: planning, acting, observing, and reflecting. In cycles 1 and 2 the actions taken with the cooperative learning model script. As a result, it can be concluded that the implementation of this method succeeded in increasing student learning activities. Student learning activities increased in the initial conditions of 70.77 cycle 1 reaching 74.42 then increased to 77.31 in cycle 2 , an increase of 6.54. Student learning outcomes also increased, in the initial condition 63.85 cycle 1 reached 69.23 then increased to 80 in cycle 2 so that an increase of 16.15.
\end{abstract}

\begin{abstract}
Abstrak
Permasalahan di SD 4 Karangmalang yaitu rendahnya aktivitas dan hasil belajar matematika materi operasi hitung campuran. Penelitian ini memiliki tujuan untuk: (1) meningkatkan aktivitas belajar matematika tentang operasi hitung campuran dengan model pembelajaran cooperatif script, dan (2) meningkatkan hasil belajar matematika tentang operasi hitung campuran dengan model pembelajaran cooperatif script. Penelitian tindakan kelas dilakukan pada siswa kelas VI SD 4 Karangmalang semester I Tahun 2017/2018 dengan jumlah siswa 13 terdiri dari 9 siswa putra dan 4 siswa putri. Metode yang digunakan dalam penelitian ini adalah penelitian tindakan kelas yang terdiri dari 2 siklus, masing-masing siklus terdiri dari 4 tahapan yaitu perencanaan, pelaksanaan, pengamatan, dan refleksi. Pada siklus 1 dan 2 tindakan yang dilakukan dengan model pembelajaran cooperatif script. Hasilnya, dapat disimpulkan bahwa pelaksanaan dengan metode ini berhasil meningkatkan aktivitas belajar siswa. Aktivitas belajar siswa meningkat pada kondisi awal 70,77 siklus 1 mencapai 74,42 kemudian meningkat menjadi 77,31 pada siklus 2, terjadi peningkatan sebesar 6,54 . Hasil belajar siswa juga meningkat, pada kondisi awal 63,85 siklus 1 mencapai 69,23 kemudian meningkat menjadi 80 pada siklus 2 sehingga terjadi peningkatan sebesar 16,15 .
\end{abstract}

\footnotetext{
Alamat korespondensi:

Program Studi Pendidikan Matematika

Fakultas Keguruan dan Ilmu Pendidikan Universitas Muria Kudus

Kampus UMK Gondangmanis, Bae Kudus Gd. L. 1t I PO. BOX 53 Kudus

Tlp (0291) 438229 ex.147 Fax. (0291) 437198

E-mail: s.rosiah12@gmail.com
} p-ISSN 2615-4196 


\section{PENDAHULUAN}

Mata pelajaran matematika perlu diberikan kepada semua siswa mulai dari sekolah dasar untuk membekali siswa dengan kemampuan berpikir logis, analitis, sistematis, kritis, dan kreatif, serta kemampuan bekerjasama (Saefudin, 2012). Kompetensi tersebut diperlukan agar siswa dapat memliliki kemampuan memperoleh, mengelola, dan memanfaatkan informasi untuk bertahan hidup pada keadaan yang selalu berubah, tidak pasti, dan kompetitif.

Berdasarkan hasil observasi menunjukkan bahwa pada kondisi awal pada pembelajaran matematika tentang operasi bilangan campuran hasil belajar siswa rendah. Hal ini ditunjukkan dengan rata-rata kelas hanya mencapai 63,85. Rata-rata kelas tersebut masih berada di bawah KKM Matematika, yaitu 70.

Hasil observasi tersebut mengindikasikan bahwa terdapat kesenjangan antara kenyataan dan harapan. Oleh karena itu dapat diidentifikasi masalah pembelajaran matematika antara lain guru masih mendominasi pembelajaran, siswa tidak sepenuhnya ikut aktif dalam proses pembelajaran matematika, guru belum memanfaatkan model pembelajaran yang tepat.

Hal di atas menuntut guru untuk segera melaksanakan perbaikan pembelajaran yang mengaktifkan siswa dan guru agar aktivitas pembelajaran meningkat. Adapun alternatif yang dapat digunakan adalah dengan menggunakan model pembelajaran cooperatif script.

Hasil penelitian menunjukkan bahwa terdapat perbedaan hasil belajar siswa antara siswa yang diajar dengan menerapkan metode cooperative script dan yang diajar dengan menerapkan metode ceramah (Puryanti dan Maryamah, 2015).

Pembelajaran cooperative script penting dilakukan karena pembelajaran dengan model ini memiliki peran strategis untuk mendongkrak hasil belajar siswa. Dalam implementasi pembelajaran cooperative script guru akan menyesuaikan kondisi dan karakteristik siswa, sehingga diharapkan guru dapat menyampaikan materi secara tepat dan tidak menimbulkan kebosanan bagi siswa (Salamiah, 2018).

Model pembelajaran cooperatif script ini tidak hanya unggul dalam membantu siswa memahami konsep yang sulit, tetapi juga sangat berguna untuk menumbuhkan kemampuan berfikir kritis, bekerjasama, dan membantu teman. Kelebihan model pembelajaran cooperatif script yaitu: (1) melatih pendengaran, ketelitian/kecermatan, (2) setiap siswa mendapat peran dalam diskusi, setiap siswa mendapatkan kesempatan untuk mengungkapkan ide atau pendapatnya, (3) melatih siswa mengevaluasi hasil diskusi untuk diselesaikan bersama (Huda, 2013).

Keberhasilan pencapaian tujuan pendidikan terutama ditentukan oleh proses belajar mengajar yang dialami siswa. Siswa dalam belajar diharapkan mampu mengalami perubahan baik dalam aspek kognitif, afektif, dan psikomotorik. Sikap-sikap yang harus diambil guru dalam proses pembelajaran hendaknya sesuai dan mampu membangkitkan aktivitas belajar siswa serta meningkatkan hasil belajar siswa. Perolehan nilai yang di bawah KKM diharapkan ada peningkatan.

Penelitian ini memiliki tujuan penelitian sebagai berikut: (1) meningkatkan aktivitas belajar matematika tentang operasi hitung campuran dengan model pembelajaran cooperatif script, (2) meningkatkan hasil belajar matematika tentang operasi hitung campuran dengan model pembelajaran cooperatif script. Melalui pembelajaran cooperatif script diharapkan siswa menjadi lebih aktif dan hasil belajarnya meningkat. Dari permasalahan dan kajian yang telah diuraikan maka hipotesis tindakan adalah model pembelajaran cooperatif script dapat meningkatkan aktivitas dan hasil belajar matematika tentang operasi hitung campuran pada siswa kelas VI SD 4 Karangmalang semester I Tahun 2017/2018.

\section{METODE PENELITIAN}

Penelitian ini menggunakan jenis penelitian tindakan kelas. Pelaksanaan penelitian tindakan kelas ini di kelas VI SD 4 Karangmalang Kecamatan Gebog Kabupaten Kudus tahun pelajaran 2017/2018. Merupakan salah satu sekolah dengan penghijauan yang sejuk dan indah membuat suasana sekolah nyaman untuk pembelajaran. Selain itu kelas untuk rombel lengkap dan memenuhi syarat pembelajaran yang efektif.

Subjek Penelitian Tindakan Kelas ini siswa kelas VI SD 4 Karangmalang Kecamatan Gebog Kabupaten Kudus tahun pelajaran 2017/2018 yang berjumlah 13 siswa terdiri dari 9 siswa putra dan 4 siswa putri. Sedangkan objek Penelitian Tindakan Kelas ini adalah Mata pelajaran Matematika tentang operasi hitung campuran.

Data di dalam penelitian ini meliputi: (1) data kuantitatif, yaitu data hasil belajar siswa terdiri dari data hasil belajar kondisi awal, siklus 1, dan siklus 2, serta (2) data kualitatif, yaitu aktivitas belajar yang terdiri dari data aktivitas belajar siswa pada jurnal refleksi merupakan 
aktivitas belajar kondisi awal, sedangkan data aktivitas belajar siklus I, data aktivitas belajar siklus II pada lembar observasi. Penelitian Tindakan Kelas dari siswa kelas VI SD 4 Karangmalang Kecamatan Gebog Kabupaten Kudus tahun pelajaran 2017/2018 yang berjumlah 13 siswa terdiri dari 9 siswa putra dan 4 siswa putri sebagai sumber utama penelitian tindakan kelas.

Teknik pengumpulan data dalam penelitian ini yaitu: (1) teknik dokumentasi, (2) teknik pengamatan, dan (3) teknik tes. Teknik dokumentasi berupa jurnal refleksi pembelajaran digunakan untuk mencari data kondisi awal aktivitas belajar dan hasil belajar. Dokumentasi aktivitas belajar dapat dilihat jurnal mengajar guru. Teknik pengamatan atau observasi digunakan untuk memperoleh data aktivitas belajar siswa pada siklus 1 dan 2. Pengamatan dan observasi dilakukan oleh teman sejawat selaku kolaborator yang bertugas mengamati aktivitas siswa dengan memberikan check list pada lembar observasi. Teknik tes tertulis digunakan untuk memperoleh data hasil belajar pada siklus 1 dan 2 yang dilaksanakan pada tiap akhir siklus.

Alat pengumpulan data dalam penelitian ini menggunakan dokumen daftar nilai, dokumen catatan personal, lembar observasi, dan tes tertulis. Dokumen daftar nilai digunakan untuk memperoleh data hasil belajar pada kondisi awal, Dokumen catatan personal siswa dan jurnal mengajar guru untuk memperoleh data aktivitas belajar kondisi awal. Lembar observasi/pengamatan digunakan untuk mencari data aktivitas belajar siswa pada siklus 1. Butir soal tes tertulis digunakan untuk mengukur hasil belajar pada siklus 1 dan siklus 2. Lembar observasi/pengamatan digunakan untuk mencari data aktivitas belajar pada siklus 2 .

Analisis data dilakukan melaui: 1) teknik kualitatif dan teknik kuantitatif. Teknik kualitatif digunakan untuk menganalisis aktivitas belajar siswa, sedangkan teknik kuantitatif digunakan untuk menganalisis data hasil belajar siswa.

Indikator kinerja dalam penelitian ini dilihat dari peningkatan aktivitas dan hasil belajar melalui pembelajaran dengan model pembelajaran cooperatif script. Indikator keberhasilan ditunjukkan dengan: (1) Siswa memperoleh nilai aktivitas belajar $\geq 75$, (2) Siswa memperoleh nilai rata-rata hasil belajar $\geq 70$.

Metode Penelitian Tindakan Kelas digunakan dalam penelitian ini yang terdiri dari 2 siklus. Dalam setiap siklus tindakan saling berkaitan. Pada siklus 1 dan 2 pembelajaran dilakukan dengan menggunakan model pembelajaran cooperatif script. Siklus 1 dan 2 berlangsung 4 pertemuan. Variabel yang diteliti sebagai tindakan adalah pemanfaatan model pembelajaran cooperatif script serta sebagai hasil yang dicapai aktivitas belajar dan hasil belajar.

Tahapan-tahapan dalam tiap siklus terdiri atas (1) membuat perencanaan tindakan (perencanaan), (2) melaksanakan tindakan sesuai yang direncanakan (pelaksanaan), (3) melaksanakan pengamatan terhadap tindakan yang dilaksanakan (pengamatan), (4) menganalisis dengan deskriptif komparatif dilanjutkan dengan refleksi terhadap hasil pengamatan tindakan (refleksi).

Langkah-langkah tersebut dapat digambarkan sebagai berikut.

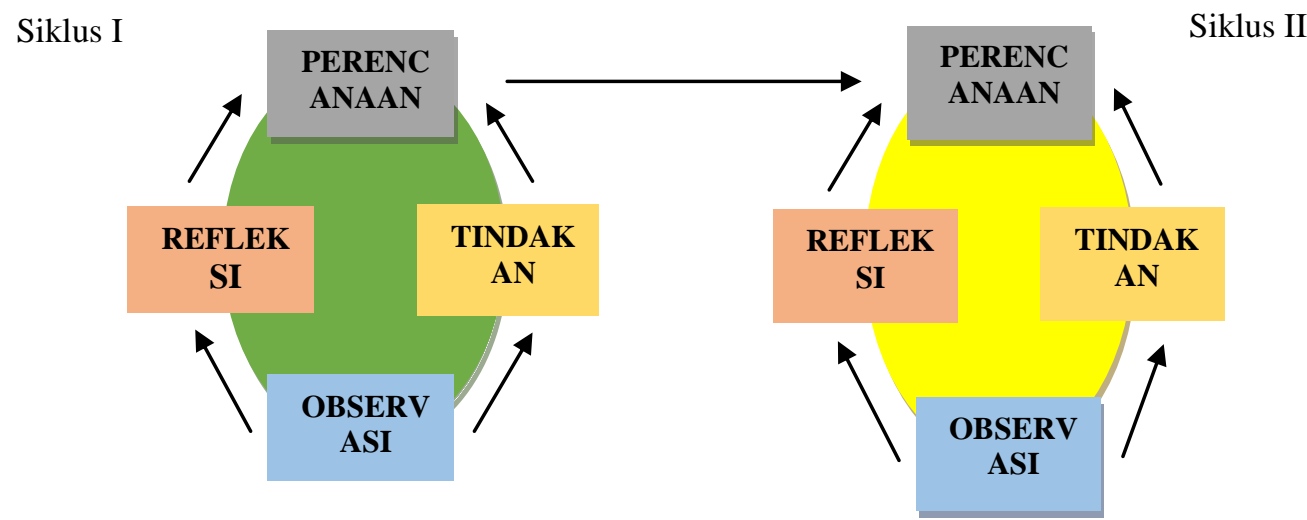

Gambar 1. Gambar Pelaksanaan Tindakan 


\section{HASIL DAN PEMBAHASAN}

Hasil penelitian yang menunjukkan perbandingan aktivitas belajar kondisi awal dan kondisi akhir siswa disajikan pada Tabel 1 berikut.

Tabel 1. Perbandingan Aktivitas Belajar Siswa

\begin{tabular}{lcc}
\hline Objek Yang Diamati & $\begin{array}{c}\text { Kondisi } \\
\text { Awal }\end{array}$ & $\begin{array}{c}\text { Kondisi } \\
\text { Akhir }\end{array}$ \\
\hline Aktivitas Belajar Siswa & 70,77 & 77,31 \\
$\begin{array}{l}\text { Aktivitas Belajar Siswa } \\
\text { Tertinggi }\end{array}$ & 75 & 80 \\
$\begin{array}{l}\text { Aktivitas Belajar Siswa } \\
\text { Terendah }\end{array}$ & 65 & 70 \\
\hline
\end{tabular}

Berdasarkan data nilai di atas dapat diketahui aktivitas siswa kondisi awal 70,77 dan pada kondisi akhir 77,31. Hasil ini menunjukkan terjadi peningkatan secara signifikan sebesar 6,54 poin. Hal ini tercapai dikarenakan telah diterapkannya model pembelajaran cooperatif script untuk mengatasi rendahnya aktivitas belajar siswa dalam pembelajaran matematika tentang operasi hitung campuran.

Perbandingan hasil belajar siswa pada kondisi awal dan kondisi akhir ditunjukkan sebagai berikut.

Tabel 2. Perbandingan Hasil Belajar Siswa

\begin{tabular}{|c|c|c|c|}
\hline \multirow[b]{2}{*}{ No } & \multirow{2}{*}{$\begin{array}{l}\text { Objek } \\
\text { diamati }\end{array}$} & \multicolumn{2}{|c|}{ Perolehan } \\
\hline & & $\begin{array}{c}\text { Kondisi } \\
\text { Awal }\end{array}$ & $\begin{array}{c}\text { Kondisi } \\
\text { Akhir }\end{array}$ \\
\hline 1 & Rata-rata & 63,85 & 80 \\
\hline 2 & Nilai tertinggi & 80 & 100 \\
\hline 3 & Nilai terendah & 50 & 60 \\
\hline
\end{tabular}

Hasil pengamatan hasil belajar siswa yang ditunjukkan dengan rata-rata siswa meningkat 16,15 dari kondisi awal 63,85 pada kondisi akhir mencapai 80 . Hal ini membuktikan bahwa pada kondisi akhir aktivitas dan hasil belajar siswa dapat ditingkatkan dan telah mencapai target penelitian setelah dibelajarkan dengan model pembelajaran cooperatif script.

Penelitian ini menerapkan pembelajaran dengan model pembelajaran cooperatif script pada siklus I dan II untuk meningkatkan aktivitas belajar siswa. Penelitian dilakukan dalam pembelajaran matematika materi operasi hitung campuran. Sintaks model pembelajaran cooperatif script yang dilakukan dalam penelitian ini yaitu siswa dibagi menjadi beberapa kelompok berpasangan kemudian diberikan tugas untuk mempelajari dan meringkas materi. Selanjutnya guru dan siswa menentukan pembaca dan pendengar. Pembicara bertugas sebagai pembaca ringkasan/penyelesaian masalah, sedangkan pendengar bertugas untuk menyimak dan membantu menambahkan penjelasan yang dihubungkan dengan materi sebelumnya/lainnya. Setelah itu, siswa diminta untuk bertukar peran. Pembelajaran diakhiri dengan membuat kesimpulan.

Sintaks yang dilakukan dalam penelitian ini sesuai dengan sintaks pembelajaran cooperatif script yang meliputi: (1) Guru membagi siswa untuk berpasangan, (2) Guru membagikan wacana/materi kepada masingmasing siswa untuk dibaca dan membuat ringkasan, (3) Guru dan siswa menetapkan siapa yang pertama berperan sebagai pembicara dan siapa yang berperan sebagai pendengar, (4) Sesuai kesepakatan siswa yang menjadi pembicara membacakan ringkasan atau prosedur pemecahan masalah selengkap mungkin, dengan memasukkan ide-ide pokok dalam ringkasan dan pemecahan masalahnya. Sementara pendengar: (a) Menyimak /mengoreksi/menunjukkan ide-ide pokok yang kurang lengkap; (b) Membantu mengingat/menghafal ide-ide pokok dengan menghubungkan materi sebelumnya atau dengan materi lainnya, (5) Bertukar peran, semula sebagai pembicara ditukar menjadi pendengar dan sebaliknya. Serta lakukan seperti diatas, (6) Guru bersama siswa membuat kesimpulan (Riyanto, 2009; Suprijono, 2010; Sani, 2013).

Aspek-aspek aktivitas belajar siswa yang diamati dalam penelitian tindakan kelas ini meliputi: (1) Siswa dapat bekerja sama dengan pasangan, (2) Siswa dapat bertukar tugas dengan pasangan, (3) Dapat berkompetisi dengan baik, (4) Memberikan tanggapan teman. Indikator tersebut dinilai untuk mencerminkan pembelajaran yang aktif dan student centered. Hal ini senada dengan pendapat bahwa pembelajaran seyogyanya dapat berperan sebagai alat untuk menciptakan proses mengajar dan belajar (Sudjana, 2013).

Langkah model pembelajaran cooperatif script pada siklus I dan II menyebabkan peningkatan aktivitas belajar siswa meningkat sebesar 6,54 dari kondisi awal 70,77 pada kondisi akhir mencapai 77,31. Hal ini membuktikan bahwa dengan model pembelajaran cooperatif script pada siklus I dan 
II dapat meningkatkan aktivitas belajar matematika tentang operasi hitung campuran bagi siswa kelas VI SD 4 Karangmalang Kecamatan Gebog Kabupaten Kudus Semester I Tahun Pelajaran 2017/2018. Hasil penelitian ini sejalan dengan beberapa penelitian yang menunjukkan bahwa pengguanan metode cooperative script dapat meningkatkan aktifitas belajar siswa (Hasnibeti, 2017; Hajaryanti dan Kuraedah, 2018).

Penerapan model pembelajaran cooperative script dapat meningkatkan aktifitas belajar siswa dalam mata pelajaran matematika tetapi di sisi lain model ini memiliki kekurangan. Kekurangan model tersebut yaitu: (1) tidak dapat digunakan untuk semua mata pelajaran, (2) setiap kelompok hanya terdiri dari dua orang, yaitu sebagai pembicara dan pendengar, dan (3) membutuhkan waktu yang relatif lama (Hamadi, 2009; A'la 2011).

Model pembelajaran cooperatif script pada siklus I dan II juga dapat meningkatkan hasil belajar siswa. Penerapan model pembelajaran cooperatif script dapat meningkatkan hasil belajar siswa sebesar 16,15 poin ditunjukkan dengan rata-rata siswa kondisi awal 63,85 kondisi akhir mencapai 80. Hal ini membuktikan bahwa model pembelajaran cooperatif script dapat meningkatkan hasil belajar matematika tentang operasi hitung campuran bagi siswa kelas VI SD 4 Karangmalang Kecamatan Gebog Kabupaten Kudus Semester I Tahun Pelajaran 2017/2018.

Hasil penelitian tersebut sejalan dengan beberapa penelitian yang menunjukkan bahwa penerapan model pembelajaran cooperative script dapat meningkatkan hasil belajar siswa (Hidayat, 2012; Fardilah, 2013; Hasanah, 2013; Rozi, Harmoko, dan Teresa, 2018). Pembelajaran cooperative script dilakukan secara berkelompok. Dalam penerapannya, pembelajaran ini dapat melatih siswa untuk saling bertukar pendapat dengan kelompok lain (Hidayatulloh, 2016). Hal ini akan membantu siswa untuk mengintegrasikan pengetahuan dan pengalaman yang diperoleh menjadi suatu pengetahuan baru. Dengan demikian pembelajaran cooperative script dapat meningkatkan semangat belajar dan berdampak pada hasil belajar siswa menjadi lebih baik.

Penerapan pembelajaran cooperative script dapat memberikan hasil yang lebih baik jika dibandingkan dengan pembelajaran dengan metode ceramah. Hal ini disebabkan karena dalam metode ceramah hanya guru yang aktif dan guru hanya menyajikan materi secara lisan dan secara langsung terhadap siswa (Daryanto, 2013).

\section{SIMPULAN}

Berdasarkan hasil penelitian dan pembahasan yang telah diuraikan sebelumnya, dapat disimpulkan bahwa pelaksanaan pembelajaran Matematika tentang operasi hitung bilangan menerapkan model pembelajaran cooperatif script dinyatakan berhasil meningkatkan aktivitas belajar siswa. Hal ini ditandai aktivitas belajar siswa yang terus meningkat pada kondisi awal 70,77 siklus 1 mencapai 74,42 kemudian meningkat menjadi 77,31 pada siklus 2 sehingga terjadi peningkatan sebesar 6,54.

Pelaksanaan pembelajaran matematika tentang operasi hitung bilangan menerapkan model pembelajaran cooperatif script dinyatakan berhasil meningkatkan hasil belajar siswa. Hal ini ditandai hasil belajar siswa yang terus meningkat pada kondisi awal 63,85 siklus 1 mencapai 69,23 kemudian meningkat menjadi 80 pada siklus 2 sehingga terjadi peningkatan sebesar 16,15 .

\section{DAFTAR PUSTAKA}

A'la, Miftahul. 2011. Quantum Teaching. Yogyakarta: Diva Press.

Daryanto, 2013. Strategi dan Tahap Mengajar Bekal Keterampilan Dasar Bagi Guru. Bandung: Yrama Widya.

Fardila, E. 2013. Pengaruh Strategi Cooperative Script dengan Media Gambar terhadap Motivasi dan Hasil Belajar Biologi Siswa Kelas VII MTS Al Raisiyah Sekarbela Tahun Pelajaran 2013/2014. Jurnal Pendidikan Sains, 2 (2): 76-81.

Hajaryanti dan St. Kuraedah. 2018. Meningkatkan Aktivitas dan Hasil Belajar Pendidikan Agamai Islam Melalui Model Pembelajaran Cooperative Script. Jurnal Al-Ta'dib, 11 (1): 154-170.

Hamadi, H. 2009. Metode Pembelajaran Skrip Kooperative (Cooperative Script). Bandung: Pusat Ilmu.

Hasanah, N. 2013. Perbandingan Hasil Belajar Siswa pada Pembelajaran Cooperative Script dan Artikulasi Materi Gerak Tumbuhan. Jurnal Pendidikan Biologi, 1 (3): $1-12$.

Hasnibeti. 2017. Penerapan Metode Cooperative Script Dalam Meningkatkan Hasil 
Belajar Siswa Kelas IV SD Pada Mata Pelajaran Matematika. Sura Guru: Jurnal Ilmu Pendidikan Sosial, Sains, dan Humaniora, 3 (3): 427-436.

Hidayat, R. 2012. Penerapan Model Pembelajaran Cooperative Script terhadap Hasil Belajar Biologi Siswa Kelas VIII SMPNegeri 1 Makassar. Jurnal Pendidikan Biologi. 1 (2): 1-7.

Hidayatulloh. 2016. Hubungan Model Pembelajaran Cooperative Script Dengan Model Pembelajaran Cooperative SQ3R Terhadap Hasil Belajar Matematika Siswa Sekolah Dasar. TERAMPIL, Jurnal Pendidikan dan Pembelajaran Dasar, 3 (2): 1-20.

Huda, M. 2013. Model-model Pengajaran dan Pembelajaran. Yogyakarta: Pustaka Belajar.

O’Donnell, A. M. 2006. The Role of Peers and Group Learning. In P.A. Alexander \& P.H. Winne (Eds.), Handbook of Educational Psychology $\left(2^{\text {nd }} e d ., \quad p p\right.$. 781-802). Mahwah, NJ: Erlbaum.

O'Donnell, A.M. 2006. The Role of Peers and Group Learning. In P. A. Alexander \& P. H. Winne (Eds.), Handbook of educational psychology (pp. 781-802). Mahwah, NJ, US: Lawrence Erlbaum Associates Publishers.

Puryanti, E. dan Maryamah. 2015. Penerapan Metode Cooperative Script Terhadap Hasil Belajar Siswa Kelas V Pada Mata Pelajaran SKI di Madrasah Ibtidaiyah Nurul Huda Kabupaten Oku Timur. JIP (Jurnal Ilmiah PGMI). 1 (2): 303-330.

Riyanto, Y. 2009. Paradigma Baru Pembalajaran. Jakarta: Kencana Prenada Media Grup.

Rozi, Z.F., Harmoko, dan Teresa, F.L. 2018. Pengaruh Model Cooperative Script Terhadap Aktivitas dan Hasil Belajar Biologi Siswa Kelas VIII SMP Negeri 7 Lubuklinggau. Jurnal Pendidikan Biologi dan Sains (BIOEDUSAINS), 1 (1): 23-33.

Saefudin, A.A. 2012. Pengembangan Kemampuan Berpikir Kreatif Siswa dalam Pembelajaran Matematika Dengan Pendekatan Pendidikan Matematika Realistik Indonesia (PMRI). Jurnal AlBidayah, 4 (1): 37-48.

Salamiah. 2018. Penerapan Model Pembelajaran Kooperatif Tipe Script Untuk
Meningkatkan Hasil Belajar Bahasa Indonesia Pada Materi Menyimak Cerita Siswa Kelas VI SD Negeri 020 Tembilahan Hilir. Jurnal PAJAR (Pendidikan dan Pengajaran), 1 (1): 110.

Sani, R.A. 2013. Inovasi Pembelajaran. Jakarta: Bumi Aksara.

Slavin, R.E. 2014. Cooperative Learning and Academic Achievement: Why Does Groupwork Work? Anales de Psicología, 30 (3): 785-791.

Sudjana, Nana. 2013. Dasar-dasar Proses Belajar Mengajar. Bandung: Sinar Baru Al-Gensindo Offset.

Suprijono, A. 2010. Cooperative Learning Teori dan Aplikasi PAIKEM. Yogyakarta: Pustaka Belajar. 